実験的高血圧ラット腎臓の2,3の酵素の組織化学的研究

尖 证.

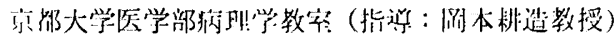

\title{
Histochemical Studies on Renal Enzymes of the Rats with Various Experimental Hypertension
}

\author{
Tadashi Okuda \\ Department of Pathology, Kyoto University School of Medicine \\ (Director: Prof. K. OKAMOTO)
}

It is generally recognized at present there exists a certain vasopressor mechanism in kidney.

Having been suggested by many investigators ${ }^{10,13,27)}$ that some enzyme systems may participate in the formation of the renal pressor principle, it seems to be interesting to study histochemically renal enzymes in experimental hypertension. Employing TTC as a histochemical indicator, Zweifach, Black \& Shorr ${ }^{27}$ ) demonstrated that formazan granules in the proximal convoluted tubules were coarse and irregular in shape with a tendency to precipitate extracellulary and that there was parallelism between this finding and VEM formation both in the experimental renal hypertension of rats and dogs and in the human hypertension. Mustakallio et al $^{13}$ also found that TTC reduction in the proximal convoluted tubules of DCA hypertension in rats was normal, but in the kidney of renal hypertension formazan granules precipitated as coarse irregular ones with focal inactive areas. They ${ }^{18}$ found also that amine oxidase activities normally located in juxtaglomerular position only, were decreased in both renal and DCA hypertensive rats. Hess \& Pearse ${ }^{103}$ demonstrated that a higher activity of glucose-6-phosphate dehydrogenase in the macula densa could be seen in the clamped kideny in the rat rendered hypertensive by unilateral clamping of the renal artery. Furthermore, Hartroft et $\mathrm{al}^{8,9)}$ and Tobian et $\mathrm{al}^{23-25)}$ recently established a relationship of the stainable juxtaglomerular granulation to hypertension.

As reported previously in our laboratory ${ }^{16)}$, a spontaneous hypertension develops in the offsprings born from ancestors induced hypertension by DCA and Skelton's ${ }^{21)}$ method for successive generations. The purpose herein is to present both data obtained from histochemical studies on some renal enzymes and changes in juxtaglomerular granulation in several kinds of experimental hypertension of the rat including our congenital hypertensive rats. 


\section{Materials and Methods}

1. Experimental animals

Wistar strain albino rats (both sexes) which were supplied from The Animal Center of Kyoto University were made hypertensive by the following 5 methods:

(1) silk perinephritis method (Page ${ }^{17)}$

(2) DCA administration 4,20,

(3) adrenal regeneration hypertension (Skelton) ${ }^{21)}$

(4) bilateral common carotid arteries ligation and drinking of $1 \%$ sodium chloride solution (cerbral hypertension; the method to rabbits described by Rosenfeld ${ }^{18)}$ was modified to rats)

(5) renal infarction method (Loomis) ${ }^{12}$ These rats were sacrificed after various duration of hypertension. The rats with experimental congenital hypertension ${ }^{16)}$ were sacrificed at 12-17 months after development of hypertension and 9 normal rats 4-12 months old were served as the control.

2. Measurement of blood pressure

Systolic blood pressure was determined by the electric manometer of Nakao $^{14)}$ using the tail.

3. Histochemical methods

The kidneys were removed immediately after sacrifice. Succinic dehydrogenase activity was demonstrated in fresh frozen sections by the method of Wachstein \& Meisel (the incubation period was 75 minutes).

Another parts of the kidneys were fixed in ice-cold acetone or acetonealcohol mixture and paraffin sections werte prepared for demonstrating acid phosphatase (by Gomori's method), ") alkaline phosphatase (by Gomori's method $)^{6)}$ and lipase (by the method of Takeuchi et al).22)

4. Observation of the juxtaglomerular granulation

Slices of renal tissue excised from a mid portion of each kidney through the transverse plane were fixed in the fixative (to 21cc. of Zenker's fluid adding $5 \mathrm{cc}$. of formalin) and then treated with $4 \%$ potassium dichromate solution for 24 hours and embedded in paraffin. The sections were stained by dahlia stain. ${ }^{3 \prime}$

In order to assess for the number of granules semiquantitatively, juxtaglomerular granulation index (J.G.I.) based on Hartroft's method ${ }^{8)}$ was calculated for each kidney as follows.

The cell, in which a few granules were contained, was graded as 1; the cell with a moderate number of granules was graded as 2 ; the cell with densely packed granules was graded as 3 . Then, the number of granules of the cells which constitute a apparatus was summed up. All glomeruli were counted such a way under binocular microscope and the total number of granules was then expressed per 100 glomeruli to obtain the indices of granulation of juxtagolmerular cells.

5. Calculation of the degree of renal arterial and arteriolar thickening. 
Wall-thickness/lumen-diameter of all small arteries and arterioles encountered through entire cortical area of section (hematoxylin- eosin stain) were measured and average wall/lumen ratio of each kidney was assessed for the degree of arterial thickening.

\section{Experimental results}

\section{Succinic dehydrogenase}

Normal control

Enzyme activity was found diffusely in all the tubular system execept of inner medullary zone (Fig. 1). In the proximal convoluted tubules formazan deposits were found in the form of numerous fine dust-like granules with a few coarse ones (Fig. 2). Distal segments of the proximal convolutions showed less intense staining but some tubules in the inner cortical zone and many tubules located within the outer medullay zone showed an intense staining due to the deposition of coarse, purplish granules.

Renal hypertension (Page's method)

An abnormal finding was found in the proximal convoluted tubules. For. mazan granules in the form of coarse clumps, fan-shaped plaques or needles arranged in rosettes much increased in number and the fine granules decreased in number on the contrary (Fig. 3).

In addition to this finding, in some kidneys focal inactive or much less active areas in outer cortices were seen.

Cerebral hypertension

Normal appearance or a slight increase in number of fine formazan deposits was observed.

DCA hypertension and adrenal regeneration hypertension.

In the early stage of hypertension formazan precipitated as fine dust-like granules in the proximal convoluted tubules, whereas in some rats with hypertension of long-term duration, formazan granules were coarse as in the renal hypertension.

Experimental congenital hypertension

13 rats with hypertension of long-term duration (12-17months) were studied. In 2 rats, the activity did not differ much from the normal control but in the remaining 11 , a significant increase in amount of coarse formazan granules in the proximal convoluted tubules was found, moreover, in 6 of these 11 rats inactive or very hypoactive focal areas were scattered in the cortices (Fig. 4, Fig. 5).

Since abnormal findings tended to appeare in the rats with hypertension of long-term duration, correlation of the grade of renal arterial thickening to the appearance of the abnormal findings was investigated in the normal control and the rats with DCA, adrenal regeneration and the experimental congenital hypertension. As shown in Tab. 1, abnormal finding similar to that in renal hypertension was observed on the rats with significant renal arterial thickening. 


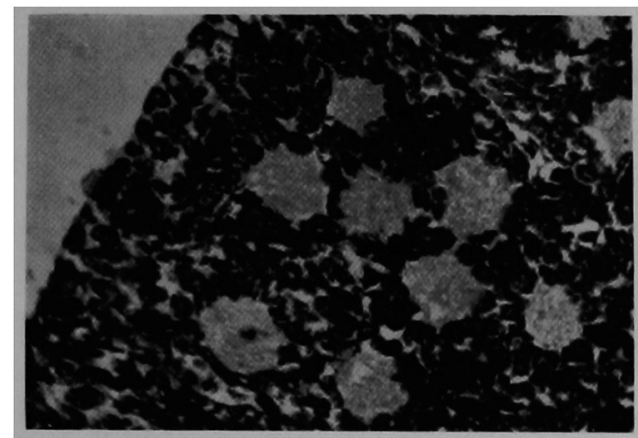

Fig. 1. Succinic dehydrogenase activity in the renal cortex of nomal rat. (X80)

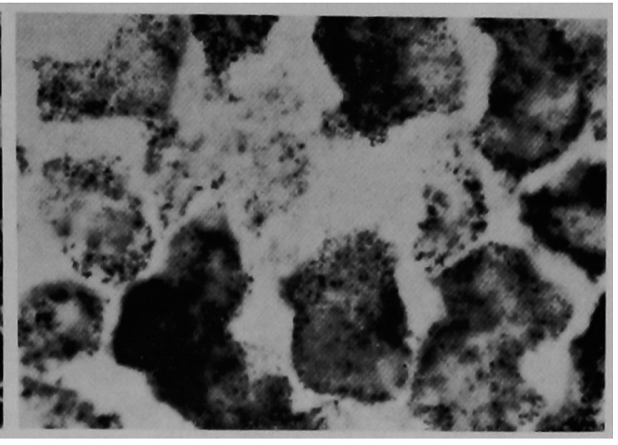

Fig. 2. Higher magnification of the same section. Numerous fine dust-like granules (X400)

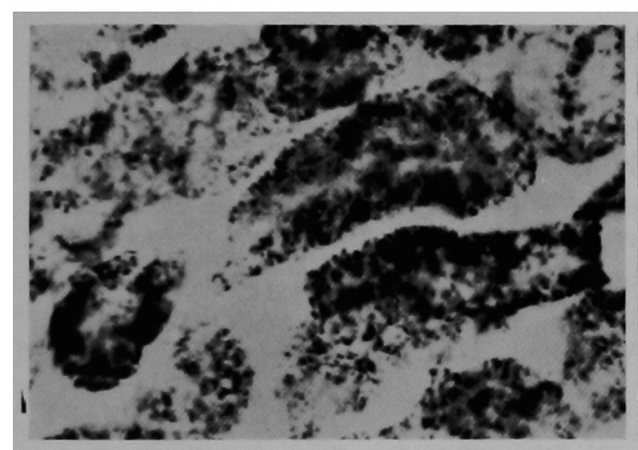

Fig. 3. Succinic dehydrogenase activity in the renal cortex of perinephritic hypertensive rat. Significant increase of the coarse irregular formazan granules. (X400)

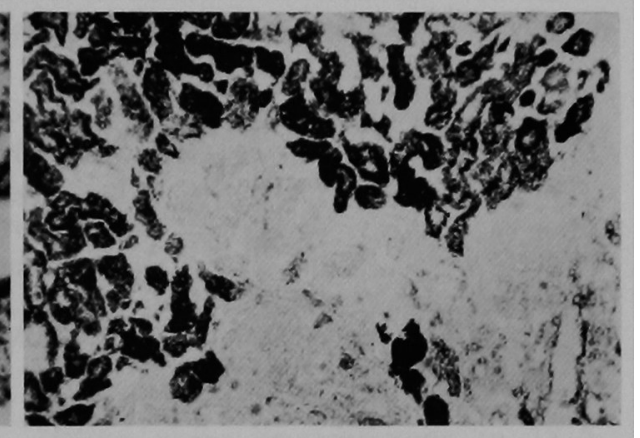

Fig. 4. Succinic dehydrogenase activity. Kidney of the experimental congenital hypertension (W416). There is focal disappearance of activity. (X100)

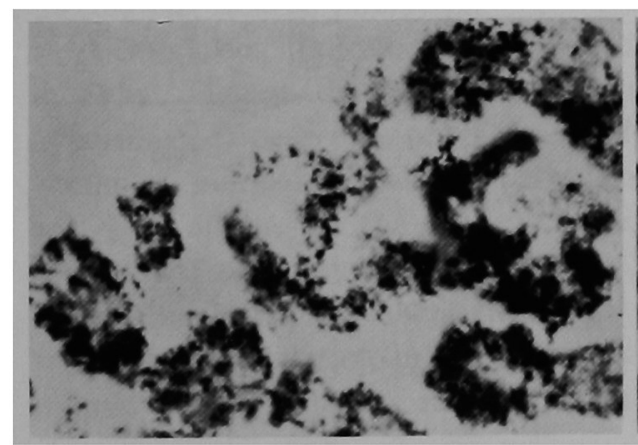

Fig. 5. Succinic dehydrogenase activity. Kidney of the experimental congenital hypertension (H539). Marked increase of the coarse formazan granules. (X400)

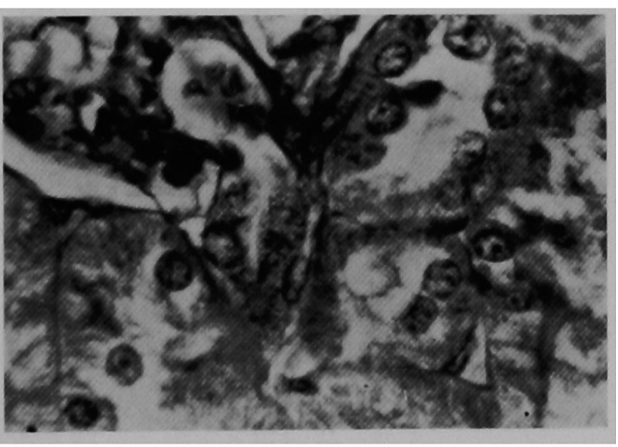

Fig. 6. Juxtaglomerular apparatus of normal rat. Dahlia stain. (X1000) 


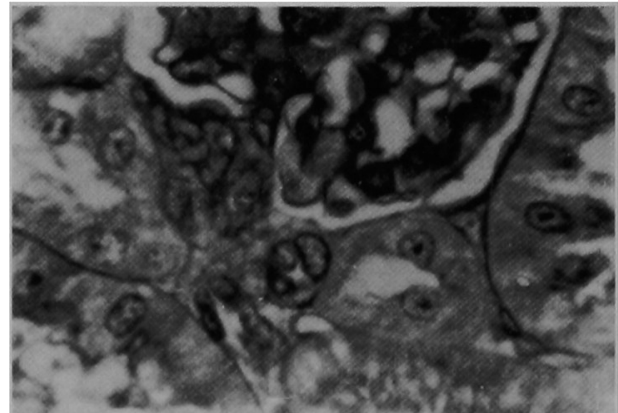

Fig. 7. Degranulated juxtaglomerular apparatus. H552, a rat of the experimental congenital hypertension. Dahlia stain. (X1000)

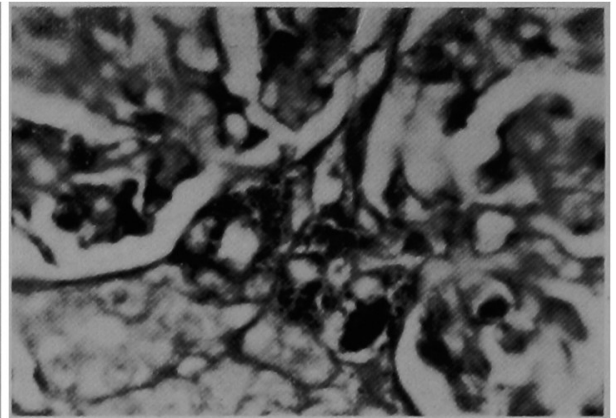

Fig. 8. Hypergranulated apparatuses in the vicinity of infarcted area. RIH 2, a rat of the renal infarction hypertension. Dahlia stain. (X1000)

Table. 1 Degree of Renal Arteriolar Thickening and Succinic Dehydrogenase Activity

\begin{tabular}{|c|c|c|c|c|c|c|}
\hline $\begin{array}{l}\text { Kind of } \\
\text { experiment }\end{array}$ & $\begin{array}{l}\text { Animal } \\
\text { number }\end{array}$ & Sex & $\begin{array}{c}\text { Age } \\
\text { (Duration of } \\
\text { hypertension) }\end{array}$ & $\begin{array}{l}\text { Systolic } \\
\text { blood } \\
\text { pressure }\end{array}$ & $\begin{array}{l}\text { Degree of } \\
\text { renal } \\
\text { arteriolar } \\
\text { thickening }\end{array}$ & $\begin{array}{l}\text { Succinic } \\
\text { dehydrogen- } \\
\text { ase* activity } \\
\text { in the kidney }\end{array}$ \\
\hline $\begin{array}{l}\text { Normal } \\
\text { Control }\end{array}$ & 9 & $\begin{array}{ll}\hat{0} & 5 \\
\text { o } & 4\end{array}$ & 4-18 Months & $\begin{array}{r}121 \\
\pm 7\end{array}$ & $\left(0.88^{1.1 .14}\right)$ & $(-)$ \\
\hline $\begin{array}{l}\text { DCA } \\
\text { hypertension }\end{array}$ & $\begin{array}{lr}\text { DH } & 1 \\
\text { DH } & 2 \\
\text { DH } & 3 \\
\text { DH } & 5 \\
\text { DH } & 6 \\
\text { DH } & 11 \\
\text { DH } & 12\end{array}$ & 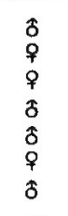 & $\begin{array}{l}(2) \text { Weeks } \\
(2) \\
(3) \\
(21) \\
(21) \\
(40) \\
(40)\end{array}$ & $\begin{array}{l}172 \\
180 \\
172 \\
186 \\
170 \\
144 \\
178\end{array}$ & $\begin{array}{l}1.24 \\
1.25 \\
1.29 \\
1.71 \\
1.43 \\
1.19 \\
1.80\end{array}$ & $\begin{array}{l}(-) \\
(-) \\
(-) \\
(H) \\
(-3) \\
(\text { HI) }\end{array}$ \\
\hline $\begin{array}{l}\text { Adrenal } \\
\text { regeneration } \\
\text { hypertension }\end{array}$ & $\begin{array}{lr}\text { ARH } & 3 \\
\text { ARH } & 4 \\
\text { ARH } & 5 \\
\text { ARH } & 7 \\
\text { ARH } & 8 \\
\text { ARH } & 9 \\
\text { ARH } & 10 \\
\text { ARH } & 11\end{array}$ & $\begin{array}{l}q \\
0 \\
q \\
q \\
\phi \\
q \\
q \\
+ \\
q\end{array}$ & $\begin{array}{l}(1) \text { Weeks } \\
(2) \\
(3) \\
(14) \\
(14) \\
(18) \\
(17) \\
(18)\end{array}$ & $\begin{array}{l}152 \\
164 \\
156 \\
164 \\
160 \\
158\end{array}$ & $\begin{array}{l}1.16 \\
0.89 \\
1.12 \\
1.20 \\
1.32 \\
1.65 \\
1.63\end{array}$ & $\begin{array}{l}(-) \\
(+) \\
(-) \\
(-) \\
(-) \\
(H) \\
(+)-(H) \\
(H)\end{array}$ \\
\hline $\begin{array}{l}\text { Experimental } \\
\text { congenital } \\
\text { hypertension }\end{array}$ & $\begin{array}{lr}\text { H } & 431 \\
\text { H } & 433 \\
\text { H } & 435 \\
\text { H } & 4505 \\
\text { H } & 518 \\
\text { H } & 530 \\
\text { H } & 536 \\
\text { H } & 539 \\
\text { H } & 546 \\
\text { H } & 552 \\
\text { H } & 562 \\
\text { W } & 412 \\
\text { W } & 416\end{array}$ & 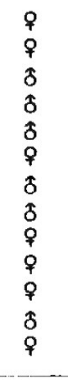 & $\begin{array}{l}21(16) \text { Months } \\
22(15) \\
21(16) \\
20(16) \\
21(16) \\
22(17) \\
17(14) \\
19(16) \\
20(16) \\
20(16) \\
16(12) \\
22(16) \\
20(14)\end{array}$ & $\begin{array}{l}154 \\
154 \\
158 \\
144 \\
170 \\
162 \\
180 \\
190 \\
158 \\
152 \\
153 \\
152 \\
162\end{array}$ & $\begin{array}{l}1.25 \\
1.82 \\
1.70 \\
1.58 \\
1.83 \\
1.77 \\
2.02 \\
1.94 \\
1.33 \\
1.54 \\
1.51 \\
1.61 \\
1.89\end{array}$ & $\begin{array}{l}(-) \\
(\text { H) } \\
(+)-(H) \\
(+) \\
(+ \text { H) } \\
(H) \\
(\text { H) } \\
(\text { H) } \\
(-) \\
(\text { H) } \\
(\text { W) } \\
(\text { W) } \\
(\text { W) }\end{array}$ \\
\hline
\end{tabular}

: Number of animals

* (-) : Normal activity

(t) : Slight increase of irregular coarse granules

(H) : Marked increase of coarse granules

(H) : Focal disappearance of activity in addition to (H) 
Table, 2 J.G.I. in Various Experimental Hypertension

\begin{tabular}{|c|c|c|c|c|c|}
\hline $\begin{array}{l}\text { Kind of } \\
\text { experiment }\end{array}$ & $\begin{array}{l}\text { Number } \\
\text { of animals }\end{array}$ & Sex & $\begin{array}{l}\text { Duration of } \\
\text { hypertension }\end{array}$ & $\begin{array}{c}\text { Average blood } \\
\text { pressure at } \\
\text { sacrifice }\end{array}$ & $\begin{array}{l}\text { Average } \\
\text { J.G.I. }\end{array}$ \\
\hline Normal control & 9 & $\begin{array}{ll}\delta & 5 \\
\wp & 4\end{array}$ & $\begin{array}{r}\text { 4-18 Months } \\
\text { old }\end{array}$ & $121+7$ & $\begin{array}{c}91.4 \pm 12.3 \\
(78.1 \quad 109.7)\end{array}$ \\
\hline $\begin{array}{l}\text { DCA hyperte. } \\
\text { nsion }\end{array}$ & 5 & $\begin{array}{ll}\delta & 2 \\
\$ & 3\end{array}$ & & 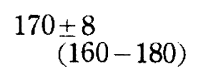 & $\begin{array}{l}0.9 \\
(0-2.7)\end{array}$ \\
\hline $\begin{array}{l}\text { Post-1 } \\
\text { hy }\end{array}$ & 4 & $\begin{array}{ll}\hat{1} & 3 \\
\wp & 1\end{array}$ & 21-40Weeks & $169 \frac{\text { 上 }}{(1}$ & \\
\hline $\begin{array}{l}\text { Adren } \\
\text { reger } \\
\text { hyp }\end{array}$ & 6 & & 1-18Weeks & $164+8$ & $\begin{array}{l}37.3 \\
(7.6\end{array}$ \\
\hline $\begin{array}{l}\text { Expe } \\
\text { cong } \\
\text { hyl }\end{array}$ & 6 & $\begin{array}{ll}\delta & 1 \\
\wp & 5\end{array}$ & $48-68$ Weeks & $157+4$ & $\begin{array}{l}26.1 \pm 5.3 \\
(21.0-35.1)\end{array}$ \\
\hline $\begin{array}{l}\text { Perinephritic } \\
\text { hypertension }\end{array}$ & $\begin{array}{rr}* \mathrm{RH} & 8 \\
\mathrm{RH} & 9 \\
\mathrm{RH} & 10 \\
\mathrm{RH} & 6 \\
\mathrm{RH} & 7\end{array}$ & $\begin{array}{l}q \\
q \\
\wp \\
q \\
q \\
q\end{array}$ & $\begin{array}{r}1 \\
\frac{2}{3} \\
12 \\
20\end{array}$ & $\begin{array}{l}172 \\
210 \\
154 \\
230 \\
161\end{array}$ & $\begin{array}{r}133.8 \\
60.7 \\
43.3 \\
0 \\
33.5\end{array}$ \\
\hline $\begin{array}{r}\text { Renal } \\
\text { hyp }\end{array}$ & 6 & \& & 1-8Weeks & $166 \frac{18}{(144-190)}$ & $\begin{array}{l}\text { (a) } 230.6 \pm 96.1 \\
\text { (b) } 24.9 \pm 13.2\end{array}$ \\
\hline $\begin{array}{l}\text { erebral } \\
\text { hypertension }\end{array}$ & 3 & $q$ & $1.5-9 \mathrm{We}$ & $160(146-174)$ & $\begin{array}{l}47.5 \\
(20.2-72.2)\end{array}$ \\
\hline
\end{tabular}

* Animal number

(a) J.G.I. in the vicinity of infarcted area

J.G.I. : Juxtaglomerular granulation index

(b) J.G.I. in the remaining part.

2. The other enzymes

Both alkaline phosphatase activity of the outer cortical zone in DCA hypertension and lipase activity in the experimental congenital hypertension decreased, and acid, and alkaline phoshatase activity disappeared from the focal areas of severe sclerotic kidneys in DCA, renal and congenital hypertension.

3. Juxtaglomerular granulation

Granulation indices (J.G.I.) in each experimental hypertension are shown in Tab.2. Though there were some differences according to the kinds of hypertension, decreases of J.G.I. i.e. degranulation were seen. Degranulation was most marked in DCA hypertension and became moderetely less in the post-DCA phase. In the congenital hypertension the index was a third of the normal average (Fig.7). In renal hypertension by Page's method the index also decreased except in one rat (RH8). In renal infarctionhypertension, hypergranulation in the glomeruli along the infarcted area and almost complete degranulation in the remaining glomeruli were characteristic (Fig. 8).

\section{Discussion}

Succinic dehyrogenase

Enzyme activity in the normal rat is identical with findings described by 
Wachstein and Meisel ${ }^{26)}, 9$ control kidneys show the same activity and there is no age difference.

In the rats with renal hypertension by Page's method the activity is the same in natur as that reported by $Z$ weifach et $\mathrm{al}^{27}$ ) and Mustakallio et $\mathrm{al}^{13)}$ using TTC as a indicator. Mustakallio et $\mathrm{al}^{13)}$ described that the activity in the kidney of DCA hypertension did not differ from that in the normotensive. The author's results, however, show that the similar abnormal findings as those in renal hypertension appeare in some kidneys of the long-term hypertensive rats (adrenal regeneration, experimental congenital as well as DCA hypertension) and indicate that occurrence of such an abnormal finding are intimately associated with renal arterial and arteriolar thickening. In other words, the kidney with advanced arterial and artriolar sclerosis as a consequence of long-lasting hypertension may show similar changes as that in renal hypertension regardless of initiating mechanism for the development of hypertension.

Mustakallio et $\mathrm{al}^{13)}$ regard coarse formazan deposits in renal hypertension as to be the consequence of swelling and conglomeration of mitochondria of the proximal convoluted tubules due to anoxia of nephrons in the ischemic kidney. As is well known that oxidizing enzymes including succinic dehydrogenase are localized in the mitochondrial famework, this interpretation seems to be reasonable. Anoxia of nephrons due to disturbance of intrarenal circulation may occur in the kidney with thickened arteries and arterioles and this alteration in nephrons may be responsible for the abnormality.

Zweifach et $\mathrm{al}^{27}$ ) suggested the similiarity between renal hypertension and human essential hypertension, since the kidneys from two hypertensive human subjects showed the similar activities with those in experimental renal hypertension. The author's results, however, show that this claim is less significant unless the observed materials are in early stage of hypertension. The congenital hypertension by our experimental procedures ${ }^{16)}$ has a resemblance to human essential hypertension in a view of morphology and pathophysiology but 2 rats of 13 studied show almost normal activiy. This fact also suggests that it is impossible to speculate the renal origin of essential hypertension by means of this enzyme activity alone.

Any significant conclusion could not be made from the data on the other enzymes than succinic dehydrogenase.

Changes in juxtaglomerular granulation

Juxtaglomerular apparatus, discovered by Ruyter ${ }^{19}$ in 1925 has been studied there-after by many investigators $\mathbf{s}^{1,2,7,8,11,15,23,21)}$ and recently Tobian ${ }^{25}$ ) concluded that stainable granules in the juxtaglomerular calls decreased when intra renal arterial pressure rose and vice versa and that these granules might be renin or its precursor. On the other hand, as described in introduction Mustakallio et al $^{133}$ found that amine oxidase which might be implicated in the formation of pressor amines, localized only in juxtaglomerular position and that the activity of this enzyme was reduced associated with the development of hypertension. Hess and Pearse ${ }^{(0)}$ observed a high activity of glucose-6-phosphate dehydrogenase in the macula densa in experimental renal hypertension 
and suggested implication of this enzyme in the formation of renin. In this way, it is worthy of note that all of 3 authors implicate the enzyme activity in renal vasopressor material.

The author's results are of stainable granules by dahlia stain. Degranulation was observed not only in the DCA and the adrenal regeneration hypertension as Tobian et $\mathrm{al}^{23)}$ did, but also in the cerebral and in the experimental congenital hypertension.

In the renal hypertension by Page's method J.G. indices decreased mostly as Bohle et al ${ }^{1)}$ reported and hypergranulation described by Tobian ${ }^{25}$, was not observed except in one rat. Bohle et al ${ }^{11}$ attribute this contradictory finding to the disparity in period after the onset of hypertension of this type. The exceptional rat with hypergranulation of J. G. cells was at early stage of hypertension which rapidly developed after silk encapsulation. It seems likely that at the early stage of hypertension intrarenal pressure falls due to constriction and therfore hypergranulation may occure but that after the development of persistent hypertension degranulation may occure with an increase of intrarenal arterial pressure.

Juxtaglomerular granulation in renal infarction hypertension has not yet been reported. The author's data show significant hypergranulation in the glomeruli along the marging of infarction and degranulation in the remaining part. Pathogenesis of renal infaction hypertension is unknown, however, if hypergranulation implies the increase of renin formation as Tobian ${ }^{25}$ ) suggested, it may be considered that renin secretion increases in the part along the margin of infarction, thus the same effect as Goldblatt's $\mathrm{s}^{5)}$ renal artery constriction on the pathogenesis of hypertension originates from this part of the kidney. Present results show that degranulation could be seen in all cases of DCA, adrenal regeneration, cerebral and experimental congenital hypertension, and in the majority of Page's renal hypertension and in renal infarction hypertension (other part than hypergranulated area). Therefore, an elevation of intrarenal arterial pressure may cause degranulation of juxtaglomerular cells.

However, whether this granules is pressor material or not and whether hypergranulation indicates hyperfunction of Juxtaglomerular apparatus or not and vice versa must await further investigations.

\section{Summary}

Succinic dehydrogenase, acid phosphatase, alkaline phosphatase and lipase activity in the kidneys of rats with hypertension induced by several experimental procedures (renal, DCA, adrenal regeneration, cerebral and experimental congenital hypertension) were studied histochemically and changes in juxta glomerular granulation were also observed.

In the kidneys of Page's perinephritic hypertension marked increase in number of irregular coarse formazan granules in the proximal convoluted tubules and focal disappearance of activity of the cortices in a few case were observed. This abnormal finding, however, was not specific for the renal 
hypertension but also was observed in the DCA, adrenl regeneration and congenital hypertension associated with thickening of the renal arterial wall.

No significant abnormal finding of the other enzymes was demonstrated.

Juxtaglomerular granules were decreased in number in all hypertensive rats, the decrease in number beeing varied slightly according to the procedures in the experiment. It was characteristic that in the renal infarction hypertension the granules was increased markedly in number in the nearest vicinity of infarcted area and was decreased in the remaining part.

\section{References}

1) Bohle, A., M. Kohler u. U. Tomsche: Zieg. Beit. f. path. Anat. u. allg. Path., 113, 414 427,1953. 2) Desprez, J.: Am.J . Clin. Path., 18, 953-960,1948. 3) Eguchi, S.: Transact. Soc. Path. Jap., 47, 323 344,1958. 4) Friedman, S.M., C. L. Friedman \& $M$. Nakashima: J. Exp. Med., 93, 361-373,1951. 5) Goldblatt, H.: Renal origin of hypertension Charles C. Thomas, Springfield, Illinois, U.S.A., 1948. 6) Gomori, G.: Microscopic Histochemistry, Univ. Chicago Press, Chicago, 1952. 7) Goormaghtigh, N.: Am. J. Path., 16, 409-415,1940. 8) Hartroft, P.M. \& W.S. Hartroft: J. Exp. Med., 97, 415-428, 1953. 9) Hartroft, P.M.: J. Exp. Med., 105, 501-508,1957. 10) Hess, R. \& A.G.E. Pearse: Brit. J. Exp. Path., 40, 243-249,1959. 11) Kaufmann, W.: Am. J. Path., 17, 620-622,1941. 12) Loomis, D.: Arch. Path., 41, 231-268,1946. 13) Mustakkalio, K.K., J.I. Saikkonen \& M. Mustakkallio: Acta med. Scand., 154, (Suppl. 312), 221-225,1956. 14) Nakao, T., K. Hiraga \& T. Yanagida: Science of organism 6,181,1955. 15) Oberling, C. : Am. J. Path., 20,155-171, 1944.16$)$ Okamoto, K. \& T. Okuda: Transact. Soc. Path. Jap., 48,1123,1959. 17) Page, I. H.: J.A.M.A., 113, 2046-2048,1939. 18) Rosenfeld, S.: Am. J. Physiol., 169, 733-737,1952. 19) Ruyter, J.H.C.: Ztschr. f. Zellforsch. u. mikr. Anat., 2, 242-248,1925. 20 ) Selye, H., C.E. Hall \& E. M. Rowley: Canad. M.A.J., 49, 88-92,1943. 21) Skelton, F.R.: Proc. Soc. Exp. Biol. \& Med., 90, 342-346,1955. 22) Takeuchi, T., M. Furuta \& K. Yoshimura: Tokio Izi Sinsi, 70, 319,1953. 23) Tobian, L. J.. Thompson, R. Twedt \& J. Janecek: J. Clin. Invest. 37,660-670,1958. 24) Tobian, L., J. Janecek \& A. Tomboulian: Proc. Soc. Exp. Biol. \& Med., 100, 94-96,1959. 25) Tobian, L.: Ann. Int. Med., 52,395-410,1960. 26) Wachstein, M. \& E. Meisel: Am. J. Path., 30, 147-165,1954. 27) Zweifach, B. W., M.M. Black \& E. Shorr: Proc. Soc. Exp, Biol. \& Med., 74,848-854,1950.

\section{網内系細胞の機能の関係について II 腹腔細胞の変態過程についての酵素組織化学的研究 細田峻・高瀬貞夫 東北大学医学部病理学教空（指尊：赤峆兼我教授）}

\section{The Relationship Between Forms and Function in the Reticuloendothelial System}

Report II

Enzymohistochemical studies on the transformation of the peritoneal macrophage.

by

Syun Hosoda and Sadao TAKASE

From the Pathological Laboratory of Prof. K. Akazaki, Tohoku University School of Medicine, Sendai, Japan.

\section{Introduction}

The history of the studies on the peritoneal macrophage divided in three 